\title{
Choroba psychiczna - cierpienie, które zmieniło prawo
}

Błażej Kmieciak (Uniwersytet Medyczny, Łódź)

\begin{abstract}
Wstęp
19 sierpnia 1994 r. uchwalono w Polsce ustawę o ochronie zdrowia psychicznego (przytaczaną dalej jako o.z.p.). Zarówno psychiatrzy, jak i prawnicy przez ponad dwadzieścia lat starali się doprowadzić do ustanowienia przepisów, które w pełni chroniłyby prawa osób poddawanych hospitalizacji psychiatrycznej. Warto w tym miejscu zwrócić uwagę na to, że leczenie tego typu ma wyjątkowy charakter. Niejednokrotnie dotyczy ono osób, które-z racji doświadczanych objawów-nie potrafią $\mathrm{w}$ pełni kompetentnie wypowiedzieć się o swoim własnym położeniu. Mowa tu również o pacjentach, którzy w okresie nasilenia choroby nie są w stanie samodzielnie zaspokajać podstawowych potrzeb życiowych. Podobny stan powodują również potęgowane objawami psychotycznymi zachowania agresywne lub autoagresywne. Sytuacje takie wielokrotnie opisywał Antonii Kępiński. Jego zdaniem,
\end{abstract}

Gdy jakiś człowiek narusza swoim zachowaniem ... hierarchię prawdopodobieństwa, gdy jego wyraz twarzy, modulacja głosu, treść wypowiedzi, czyny itd. są całkowicie niezgodne z naszym oczekiwaniem, wówczas zostaje on zakwalifikowany jako „dziwny”, „inny”, czyli nienormalny (polskie „wariat” od varius, francuskie alien od alienus). To sarno można powiedzieć o świecie, który wciąż narusza naszą hierarchię prawdopodobieństwa; staje się on światem „zwariowanym”. Jest on obcy, niezrozumiały, niekiedy odstręczający, wywołuje poczucie alienacji (Kępiński 1970, 24).

Przedstawioną przez Kępińskiego tzw. prognoza psychiatryczna można odnieść bezpośrednio do niecodziennej sytuacji, w jakiej znalazł się pacjent szpitala psychiatrycznego jako instytucji klinicznej przeznaczonej do leczenia zaburzeń i chorób psychicznych. Z jednej strony choroba psychiczna jest zjawiskiem, które fascynuje społeczeństwo. Związane $\mathrm{z}$ nią zaburzenia, pomimo kolejnych odkryć medycznych, nadal otacza aura tajemnicy. Z drugiej strony, wzbudzają one lęk; towarzyszy on również publikacjom poświęconym szpitalom psychiatrycznym. W Polsce placówki takie były przez lata sytuowane na obrzeżach wielkich miast. W wielu wypadkach są one nadal zlokalizowane w starych, zaniedbanych budynkach (Bielicka 2010, 46). Warto dodać, że bywają one kojarzone z obrazami filmowymi, w których ukazano nie 
tylko agresję osób psychicznie chorych, lecz także przemocowe zachowania personelu w stosunku do pacjentów poddawanych terapii.

Analizując historię psychiatrii dostrzegamy, że zjawisko inności, niecodzienności, dziwności itp. odbijało się wyraźnie na traktowaniu osób zaburzonych bądź upośledzonych umysłowo. Pewne sposoby traktowania, stosowane w niezbyt odległej przeszłości, postrzegane są dziś jako naruszającego fundamentalne prawa człowieka.

Aby w pełni unaocznić kontekst "inności" oraz "szczególnego położenia", warto ukazać historyczne i współczesne rozumienie praw pacjenta szpitala psychiatrycznego, określanego wciąż jeszcze przez część badaczy mianem instytucji totalnej. W takiej instytucji dozwolone jest podejmowanie działań przymusowych wobec osób poddawanych leczeniu. Czy jednak dopuszczenie takiej możliwości oznacza w swoim założeniu naruszenie praw człowieka? Czy wyjątkowa sytuacja, w jakiej znajduje się pacjent chory psychicznie, sprawia, że nadal istnieje niebezpieczeństwo dominacji i panowania szpitalnego personelu nad pacjentem? Czy szczególny charakter praw pacjenta szpitala psychiatrycznego to przykładem niezamierzonej stygmatyzacji społecznej? Czy może wskazuje on raczej na wyjątkową sytuację, wymagającą wzmożonej troski o osobę, często niezdolną do obiektywnej oceny rzeczywistość?

\section{Perspektywa historyczna}

Badając historyczne sposoby postrzegania choroby psychicznej w wybranych kulturach można dojść do wniosku, że traktowano ją niejednokrotnie jako fenomen duchowy. W starożytnym Egipcie ludzie deklarujący wgląd w niedostrzegalną dla innych rzeczywistość, słyszący niedostępne dla innych dźwięki lub głosy określali byli jako „wybrańcy bogów”, obdarzeni szczególną zdolnością do nawiązywania kontaktów ze światem nadprzyrodzonym. Opiekę nad takimi osobami często sprawowali kapłani. Pierwsze wzmianki dotyczące racjonalnego ujęcia anomalii psychicznych znajdujemy w pismach starożytnych rzymskich medyków. Zdaniem Asklepiadesa, rzymskiego lekarza żyjącego na przełomie II/I stulecia p.n.e., choroba psychiczna to nic innego, aniżeli „mechaniczne” uszkodzenie organizmu. Jego zdaniem, odpowiednie formy leczenia również powinny mieć charakter "mechaniczny”. Autor ten doradzał w pierwszym rzędzie podejmowanie takich terapeutycznych działań „psychologicznych”, jak słuchanie muzyki, kąpiele, czytanie ksiąg itd. Dopuszczał jednak także metody siłowe obejmujące przymus bezpośredni rozumiany, w tym: krępowanie chorych, podejmowane jednakże tylko w przypadkach wyjątkowych. W opinii Asklepiadesa pacjentowi przysługiwało jednak prawo powrotu do zdrowia w warunkach niewywołujących u niego lęku.

Inny rzymski lekarz, Soranos, uważał, iż poza godnym traktowaniem pacjent "chory mentalnie" ma prawo do leczenia w godnych warunkach (jasne i ciepłe pomieszczenia, obszerne sale, szerokie korytarze). W opinii Soranosa, tylko wyjątkowo można zastosować wobec pacjenta przymus. Procedura 
przymusu bezpośredniego, jaką stworzył, zezwalała na skrępowanie pacjenta za pomocą pasów. Działanie to mogło być jednak podjęte dopiero w momencie, gdy pacjent stawał się agresywny wobec siebie lub innych. W podobnych sytuacjach Soranos przyjmował, że należy zminimalizować ryzyko pojawienia się otarć na skórze pacjenta poprzez włożenie pod pasy np. wełny.

Inne zdanie w odniesieniu do pacjentów chorych psychicznie miał Aulus Cornelius Celsus, żyjący na przełomie I stulecia p.n.e./I stulecia n.e. W jego ocenie strach był czynnikiem, który na takie osoby działał najskuteczniej. Uważał, że można krępować pacjentów oraz izolować ich w piwnicach. Twierdził jednak, iż podobne działania można podejmować jedynie w wyjątkowych sytuacjach; należy przy tym oszczędzić takich działań pacjentom odczuwającym lęk przed ciemnością. Celsus zaznaczał, że w relacji z chorym potrzebny jest „dialog terapeutyczny”, wspomagany również poprzez słuchanie muzyki.

Owo psychoterapeutyczne podejście w II i III wieku n.e. rozwinął jeden z najsłynniejszych rzymskich medyków, Galen z Pergamonu. W jego ocenie choroby psychiczne miały dwojakie źródło: fizyczne oraz psychiczne. Diagnozując ich fizyczne przyczyny, zalecał podawanie chorym środków uspokajających: opium, środków drażniących, przeczyszczających, a także stosowanie specjalnej diety i ćwiczeń gimnastycznych. Warto zwrócić uwagę, iż Galen był przeciwnikiem stosowania przymusu wobec pacjentów. W jego ocenie podczas leczenia najpierw należy uspokoić pacjenta, a następnieustanowić dla niego mentora, który będzie go wspomagać w procesie powrotu do zdrowia. Zadanie mentora miało polegać przede wszystkim na wyjaśnianiu pacjentowi objawów choroby oraz przyczyn ich powstania. Ponadto, sprawował on pieczę nad pacjentem w ćwiczeniu przezeń samokontroli, co miało przyspieszyć odzyskanie przez niego równowagi psychicznej (Michalik 2008, 246 - 257).

Średniowiecze przyniosło odmienne podejście do chorób psychicznych i sposobu ich traktowania. M. in. na terenach Polski od XV w. utrwalało się stanowisko uznające nieodzowną konieczność izolacji tzw. furiatów, którzy mogli stwarzać zagrożenie dla osób zdrowych. W tym samym okresie utrwaliły się praktyki stosowania drastycznych metod wobec chorych psychicznie. Przetrzymywano ich $\mathrm{w}$ odosobnieniu, często $\mathrm{w}$ ciemnych pomieszczeniach; przykuwano do ścian łańcuchami. Podobne działania podejmowano także $\mathrm{w}$ XVIII $\mathrm{w}$. Świadczy o tym $\mathrm{m}$. in. architektura Wiedeńskiego Szpitala Powszechnego, otwartego w 1784 r. W granicach wspomnianej instytucji wybudowano tzw. „wieżę wariatów”, wyposażoną w wąskie, okratowane okna, wzmocnione metalowe drzwi, a także w pierścienie, do których można było przykuwać pacjentów (Kmieciak 2011, 64). Podobny sposób traktowania osób chorych psychicznie znany był również w kulturach pozaeuropejskich. W odległej Japonii wydano przepis nakazujący przetrzymywanie osób chorych psychicznie w specjalnych domowych celach (Totsuka 1990, 193.) Szczególne, negatywne podejście do chorych psychicznie występowało też w XVII w. na terenie obecnych Stanów Zjednoczonych 
Ameryki. Niewłaściwe poglądy utrwaliły się tam pod wpływem publikacji książkowych, takich, jak wydana w 1693 r. praca Wonders of the Invisible World (Cuda niewidzialnego świata) autorstwa Cotton Mathera, jednego $\mathrm{z}$ najbardziej w owym czasie wpływowych duchownych purytańskich. W jego ocenie wszelkie choroby psychiczne były dziełem szatana, ergo: domagały się traktowania pacjentów w sposób możliwie surowy. Traktowanie to winno obejmować również publiczne wyśmiewanie oraz karanie chłostą. Gorsze traktowanie „szaleńców” oraz „furiatów” odzwierciedlała organizacja ówczesnych szpitali. W Pennsylvania Hospital od 1753 r. wprowadzono zasadę nakazującą umieszczać pacjentów chorych psychicznie w celach, które znajdowały się w suterenie.

W literaturze przedmiotu spotkać się można z opinią, zgodnie z którą początek Rewolucji Francuskiej przynosi zmianę w sposobie traktowania chorych psychicznie (Bilikiewicz 2006, 14). W 1792 r. Phillippe Pinel w prowadzonym przez siebie szpitalu zakazał unieruchamiania pacjentów za pomocą kajdanów. Przywołane wydarzenie przedstawia się z jednej strony jako początek ery humanizmu w psychiatrii. Z drugiej strony, działanie Pinela inicjuje erę praw człowieka. W tym samym okresie także w niektórych innych krajach Europy pojawiają się zwiastuny pozytywnych przemian w opiece psychiatrycznej.

William Tuke, angielski filantrop, założył wówczas szpital York Retreat, na terenie którego wprowadził zasadę tzw. lecznictwa moralnego. W placówce tej działania terapeutyczne wprowadzano na podstawie przekonania, że pacjent doświadczający zaburzeń psychicznych wymaga specjalnego wsparcia. Osoby hospitalizowane miały prawo do spacerów oraz indywidualnych rozmów z lekarzami (Cohen \& Levi 1998, 49). Także we Włoszech od XVIII w. zachodzą istotne zmiany. Vincenzo Chiarugi uruchamia we Florencji szpital Ospedale della Carita (Szpital Miłosierdzia), którego regulamin zabrania stosowania kar cielesnych wobec pacjentów oraz umieszczania ich w niegodnych warunkach. Chiarugi zaznaczał, że leczenie chorych musi mieć charakter aktywny, uwzględniający także gry i zabawy (Grochowski 1990, 45-48).

Rozważając prawno-społeczne ujmowanie zjawiska choroby psychicznej w XIX w. warto zwrócić uwagę na dwa fakty: po pierwsze, wtedy właśnie Jean E. D. Esquirol, uczeń Pinela, dokonał rozróżnienia pomiędzy upośledzeniem umysłowym a chorobą psychiczną. Po drugie, orzecznictwo sądów amerykańskich zaczęło odwoływać się do zasady irresistible impulse (nieodpartego impulsu). Zgodnie $\mathrm{z}$ tą zasadą, wprowadzoną w 1832 r. na terenie stanu Ohio, odpowiedzialności karnej nie podlegały osoby popełniające przestępstwo na skutek doświadczanej przez nie „choroby umysłowej”. W tym samym czasie angielskie sądy wypracowały tzw. prawo Mc Naughtena, zgodnie z którym daną osobę należy uznać za niepoczytalną, jeśli w chwili dokonania czynu zabronionego nie posiadała rozeznania w zakresie własnego postępowania (Cohen \& Levi 1998, 50). 


\section{Wiek XX}

Pomiędzy końcem XIX w. a początkiem XX w. dostrzec można nowe znamiona w opiece i leczeniu osób chorych psychicznie. W okresie tym w wielu polskich miastach zdecydowano o budowie dużych ośrodków lecznictwa psychiatrycznego. Część z nich, np. łódzka Kochanówka, stała się ważnym miejscem umożliwiającym kolejnym pokoleniom lekarzy zdobywanie wiedzy i doświadczenia $\mathrm{w}$ zakresie terapii osób chorych psychicznie ${ }^{1}$. Działania podejmowane przez wspomniane placówki spotykały się z krytyką społeczną, żywą po dzień dzisiejszy. Wskazywała ona m.in. na to, że duże szpitale uniemożliwiają zindywidualizowaną opiekę medyczną. Z drugiej strony, pojawianie się takich szpitali nawiązywało do XVI-wiecznej polskiej tradycji humanitarnego traktowania chorych psychicznie (Magowska 2008, 206; 218.)

Zdarzenia, które trwale wpisały się w historię polskiej oraz światowej psychiatrii, miały miejsce w okresie III Rzeszy, zmierzającej do wykluczenia ze społeczeństwa osób cierpiących na choroby dziedziczne oraz upośledzonych umysłowo jeszcze przed rozpoczęciem działań wojennych. Po 1933 r. w kolejnych latach wprowadzano zakazy zawierania małżeństw i posiadania potomstwa z osobami wykazującymi zaburzenia o charakterze dziedzicznym. $\mathrm{Na}$ szeroką skalę uruchamiano sądy sterylizacyjne, których celem było pozbawienie możliwości prokreacyjnych osób, u których orzeczono choroby psychiczne, upośledzenia umysłowe, niepełnosprawność fizyczną.

Równolegle znowelizowany Kodeks Karny znosił karalność stosowania eutanazji. Uzasadniając jej stosowanie wskazywano, iż osoby chore i niepełnosprawne "doświadczają życia niegodnego życia". W tym miejscu koniecznie dodać należy, że wszelkie działania mające na celu eliminację ze społeczeństwa osób chorych podejmowano na podstawie odrębnych przepisów prawnych, często po uprzedniej decyzji sądu, w skład którego z mocy ustawy wchodził także lekarz (często psychiatra) (por. Katolo 2012, 5556). Z kolei już w latach dwudziestych XX w. wprowadzono praktyki określane następnie mianem tzw. „wygaszania życia”, tj. uśmiercania osób chorych psychicznie np. przez drastycznie zmniejszone racje żywności. Podobne działania popierali przedstawiciele środowisk naukowych, np. psychiatra Alfred Hoche i prawnik Karl Binding. Ich stanowiska przyczyniły się do założeń akcji T4 i akcji Brandta (1939 r.), zmierzających do eksterminacji osób chorych psychicznie, zamieszkałych na terenie III Rzeszy i terenach podbitych (Gut 2010, online). W ramach tych akcji zamierzano realizować ideologię „czystej rasy”, udostępnić miejsca w szpitalach ofiarom wojennym, a także ograniczyć kosztochłonność opieki medycznej. Dokładne dane dotyczące liczby zamordowanych pacjentów są nadal nieznane. Skalę zjawiska ukazują jednak dane dotyczące wybranych placówek: od 7 grudnia 1939 r. do 12 stycznia 1940 r. zamordowano 1.200 pacjentów Zakładu Psychiatrycznego w Dziekance niedaleko Gniezna; od 2 do 4 kwietnia 1940 r. wywieziono oraz

1 W tym czasie powstają także inne liczące się ośrodki psychiatryczne, m.in. w podwarszawskich Tworkach, Warcie, Lubiążu. 
zamordowano 499 pacjentów i pacjentek Szpitala Psychiatrycznego w Warcie. Realizacja Akcji T4 określana jest w literaturze przedmiotu jako przykład skrajnej postaci eutanazji, stosowanej na osobach chorych psychicznie. Pogląd ten nie jest jednak prawdziwy, ponieważ nazistowskie działania w żaden sposób nie odnosiły się do idei „dobrej śmierci”. Pacjentów nie pytano o zgodę na zadanie śmierci. Celem zbrodniczych praktyk nie była też chęć skrócenia cierpień fizycznych doświadczanych przez pacjentów. Naziści eliminowali jednostki zaliczane przez nich do gorszej kategorii ludzi. Dowodem na prawdziwość tej tezy są słowa naczelnego lekarza Rzeszy, dr. Gerharda Wagnera, który stwierdził, że „... nonsensem (jest), aby chorzy psychicznie, niebezpieczni dla siebie i innych, byli utrzymywaniu przy życiu kosztem wielkich wysiłków narodu" (Katolo 2012, 55).

Antonii Kępiński, analizując założenia nazistowskiej ideologii i jej reperkusje dla opieki nad umysłowo chorymi, zwracał uwagę, iż hitlerowcy w swoich działaniach dążyli nade wszystko do oczyszczenia świata z jednostek uznawanych przez nich za „podludzi”. Jak podkreślał w swej filozoficznej refleksji, podstawowym celem wszelkich obozów zagłady było „oczyszczenie rasy germańskiej $\mathrm{z}$ tego wszystkiego, co nie zgadzało się $\mathrm{z}$ ideałem germańskiego nadczłowieka". Społeczeństwo III Rzeszy w istocie wychowywane było w kulcie siły i sprawności: „nie było (w nim - uzup. B.K.) miejsca dla chorych, kalek, nienormalnych psychicznie, skażonych krwią żydowską czy cygańską" (Kępiński 2001, 5-6). Patologiczne wychowanie społeczne doprowadziło do znieczulenia na cierpienie doświadczane przez pewne grupy osób. Liczne grupy stały się dla nazistowskich lekarzy uosobieniem „obcości”, wzbudzając u nich zachowania, które Kępiński podciągnął pod kategorię „psychopatologii decyzji”. Jej najbardziej przerażające przejawy widoczne były $w$ pierwszych chwilach na terenie obozu koncentracyjnego, kiedy to obozowy lekarz SS ruchem jednej ręki, stojąc na rampie, do której docierały transporty więźniów, decydował o czyimś życiu lub śmierci (Kępiński 2001, 79).

Podobne refleksje przedstawił inny krakowski psychiatra, Eugeniusz Brzezicki $^{2}$. Jego zdaniem analiza rzeczywistości panującej w obozach koncentracyjnych skłania do stwierdzenia, że wszelkie osoby, wykonujące na ich terenach zbrodnicze rozkazy, były głęboko zaburzone. Zaliczył on personel obozowy do grona psychopatów asocjalnych i antysocjalnych (Ryn 2015, 85). Warto w tym miejscu dodać, że owe zbrodnicze działania sprawiły, iż po II Wojnie Światowej ocaleni zmuszeni byli przez wiele lat korzystać z pomocy psychiatrów. Nie potrafili powrócić do społeczeństwa, stale doświadczając dotkliwej traumy (Półtawska 2001, 54-62).

Niewyobrażalne nadużycia skłoniły środowisko międzynarodowe do wypracowania systemu gwarantującego poszanowanie praw oraz wolności osób korzystających z usług medycznych. W opinii Cezarego Mika to właśnie naruszenie praw i wolności człowieka podczas II Wojny Światowej stało się

2 Zarówno Kępiński, jak i Brzezicki byli podczas wojny więźniami obozów koncentracyjnych. 
podstawą dynamicznych działań, które przyniosły w konsekwencji przyjęcie Powszechnej Deklaracji Praw Człowieka, Europejskiej Konwencji Praw Człowieka oraz Paktów Praw Człowieka (Mik 1998, 9).

Nie można tu jednak pominąć faktu, że po zakończeniu działań wojennych nadal podejmowane były praktyki godzące $\mathrm{w}$ prawa pacjentów chorych psychicznie. Zarówno w państwach kapitalistycznych, jak i socjalistycznych wprowadzano formy terapii, które bezpośrednio naruszały prawa osób hospitalizowanych w szpitalach psychiatrycznych. Zaliczyć do nich można przede wszystkim praktyki psychochirurgiczne, w tym zwłaszcza lobotomię i elektrowstrząsy. Pierwsza z tych metod polegała na przecięciu połączeń między płatami czołowymi (powstają $\mathrm{w}$ nich urojenia), a pozostałymi częściami mózgu, odpowiedzialnymi za emocje. Zdarzali się lekarze, którzy usuwali pacjentom całe płaty czołowe. W 1949 r. dr Antoni Moniz uhonorowany został Nagrodą Nobla za odkrycia związane z zastosowaniem lobotomii $\mathrm{w}$ terapii psychiatrycznej. Obecnie środowisko medyczne jednoznaczny określa podobne działania jako procedurę medyczną naruszającą fundamentalne zasady etyki lekarskiej. W ich wyniku często dochodziło do trwałego uszkodzenia organizmu pacjenta. Po wykonanych zabiegach nie potrafili oni samodzielnie funkcjonować, wykazywali trwale zmienione zachowania, nie kontrolowali czynności fizjologicznych, cierpieli na uszkodzenia ośrodkowego układu nerwowego (Veggebrerg 1998, 109-113).

Druga $\mathrm{z}$ kontrowersyjnych metod stosowanych $\mathrm{w}$ psychiatrii, tj. elektrowstrząsy, ukazana została w sposób spektakularny w powieści i filmie pt. Lot nad kukułczym gniazdem. Pacjent poddawany elektrowstrząsom doświadczał bólu i drgawek wywołanych działaniem prądu. Sama metoda, stosowana m.in. w schizofrenii lekoopornej oraz silnych stanach depresyjnych, miała za zadanie doprowadzić do wywołania zjawiska określanego jako „zapomnienie objawów choroby przez organizm”. Obecnie wciąż niewyjaśniony jest mechanizm sprawiający, że (nadal stosowane) elektrowstrząsy przynoszą pozytywne efekty np. w terapii ostrej katatonii. Aktualnie procedury nakazują stosowanie takich zabiegów za zgodą pacjentów. Poddawany elektrowstrząsom pacjent wprowadzany jest w narkozę, a nadzór nad zabiegiem sprawuje anestezjolog (Veggebrerg 1998, 109-113).

Śledząc najnowszą historię psychiatrii nie można pominąć działań, jakie podejmowane były na terenie byłego Związku Radzieckiego. Przedstawiciele tej dyscypliny dyscypliny medycznej wykorzystywani byli do realizacji celów władzy politycznej. Już w 1959 r. Nikita Chruszczow, I sekretarz KC KPZR, publicznie zadekretował, że jedynie osoby chore psychicznie mogą być zdolne do występowania przeciwko władzy socjalistycznej. Wspomniany dekret faktycznie zezwalał na umieszczanie w tzw. psychuszkach dysydentów politycznych, których działania stały w sprzeczności z komunistycznymi ideami. W $1961 \mathrm{r}$. radzieckie Ministerstwo Zdrowia wydało instrukcję umożliwiającą przymusowe kierowanie pacjentów do szpitali psychiatrycznych w przypadku, gdy przejawiali skłonności agresywne nie 
tylko wobec drugiego człowieka, ale także wobec instytucji państwowej. Świadectwa byłych pensjonariuszy psychuszek wskazują, że personel częstokroć znęcał się nad pacjentami. Podejmowano takie działania, jak celowe stosowanie środków farmaceutycznych wywołujących ból, bicie pacjentów, owijanie ich w lodowate prześcieradła (Kmieciak 2011, 70). Ta ostatnia praktyka znana była również na terenie USA. Wspomina o niej w książce pt. Dziecko niczyje Marie Balter, osoba, która od końca lat 40-tych ubiegłego stulecia przez dwie kolejne dekady leczyła się w szpitalu psychiatrycznym. W przywołanej publikacji Balter opisuje działania, które personel wykonywał $w$ tzw. hydropracowni. Obejmowały one m.in. przymusowe mycie pacjentów, umieszczanie $\mathrm{w}$ drewnianej balii $\mathrm{z}$ wodą (wystawała z niej jedynie głowa) oraz unieruchamianie pacjentów za pomocą mokrego prześcieradła w charakterze kary (Balter 2001, 83-94).

Praktyki te doprowadziły w $1977 \mathrm{r}$. do uchwalenia dokumentu krytykującego wykorzystywanie psychiatrii w celach politycznych; uczyniono to $\mathrm{w}$ Honolulu podczas VI. Międzynarodowego Kongresu Światowego Towarzystwa Psychiatrycznego (Balter 2001, 83-94). Szczegółowo na ten temat wypowiedziała się także Organizacja Narodów Zjednoczonych, uchwalając Rezolucję $N r 119$ z dnia 17 grudnia $1991 \mathrm{r}$. w sprawie zasad ochrony osób chorych psychicznie i poprawy psychiatrycznej opieki zdrowotnej. Dokument ten stanowi, że osoba chora psychicznie w trakcie leczenia ma m.in. prawo do powrotu do zdrowia w warunkach jak najmniej uciążliwych, indywidualnego podejścia terapeutycznego, zachowania autonomii osobistej itd. Rezolucja zakazuje wymuszania zgody od pacjenta, stosowania sterylizacji oraz poddawania pacjentów przymusowo zabiegom psychochirurgicznym, a także eksperymentalnym działaniom klinicznym. Owocem obrad było ponadto uznanie, iż wszelkie działania przymusowe mogą być podejmowane wobec chorych psychicznie pacjentów jedynie i dopiero w momencie, gdy ich stan zagraża ich życiu bądź życiu i zdrowiu innych osób. Ponadto, pacjenci powinni mieć zagwarantowaną możliwość odwołania się do niezależnej władzy, kontrolującej sposób ich przyjęcia do szpitala (Pużyński 1995, 67-71).

\section{Polskie standardy}

Polska, pomimo znajdowania się przez ponad cztery dekady $w$ orbicie wpływów ZSRR, uniknęła głośnych oskarżeń o wykorzystanie psychiatrii w celach politycznych. W opinii Jacka Bomby działania takie były możliwe m. in. dzięki obecności i autorytetowi takich psychiatrów, jak Antonii Kępiński i Eugeniusz Brzezicki, którzy w swoich dziełach zwracali uwagę na humanistyczną rolę psychiatrii (Bomba 1993, 229-234). W tym miejscu zasadne jest wskazanie, że do 1994 r., tj. do czasu wejścia w życie Ustawy o ochronie zdrowia psychicznego (Ustawa, 1994), ochrona praw człowieka na terenie szpitali psychiatrycznych była na niskim poziomie. Do wskazanej daty, obszar lecznictwa psychiatrycznego regulowała jedynie Instrukcja Ministra Zdrowia z 10 grudnia 1952 r. w sprawie przyjmowania oraz wypisywania 
chorych ze szpitali psychiatrycznych. Akt ten nie gwarantował respektowania praw osób kierowanych do tych placówek. Wskazywał na możliwości umieszczenia danej osoby w szpitalu, nie określając jednak żadnych form kontroli, nie wprowadzając prawa do składania skarg i nie przewidując żadnej procedury odwoławczej (Boratyńska \& Konieczniak 2003, 390-392). Taki stan sprawiał, że zarówno polscy psychiatrzy, jak i prawnicy dążyli do uchwalenia ustawy, która w pełni chroniłaby prawa pacjentów szpitali oraz oddziałów psychiatrycznych. Stanisław Dąbrowski, współtwórca ustawy o o.z.p., zwracał uwagę, iż uchwalenie odrębnego „prawa psychiatrycznego” jest konieczne z racji na dostrzegane przez środowisko medyczne sytuacje naruszania praw pacjenta. Mowa tutaj o zdarzeniach takich, jak problemy $\mathrm{z}$ dostępem do korespondencji, ignorowanie zgody pacjenta, naruszanie godności i intymności, brak procedur i kontroli stosowania przymusu bezpośredniego (Dąbrowski 1995, 54-56). Jak zaznaczali twórcy polskiej ustawy o ochronie zdrowia psychicznego, głównym wyzwaniem w trakcie jej tworzenia było stworzenie przepisów, które $\mathrm{z}$ jednej strony w pełni gwarantowałyby poszanowanie praw i wolności osób hospitalizowanych w szpitalu; z drugiej strony dążono do stworzenia takiego systemu, który umożliwiałby lekarzowi (w pewnych wybranych okolicznościach) podjęcie działań przymusowych wobec osób, które nie potrafią pokierować własnym postępowaniem bądź podejmują działania stwarzające zagrożenie dla nich samych lub dla innych osób. W ostatecznej wersji omawiany akt prawny oparty został na zasadach: a. swobodnego dostępu pacjenta do osób mu bliskich (odwiedziny); b. konieczności wyrażenia zgody na leczenie w szpitalu psychiatrycznym; c. najmniejszej uciążliwości szpitalnego leczenia; d. dostępu do przepustek; e. szczególnej troski o zachowanie tajemnicy zawodowej przez wszystkie osoby wykonujące obowiązki wynikające z ustawy (Dąbrowski 1995, 54-56).

Przywołana wyżej zasada najmniejszej uciążliwości odnosi się do problemu stosowania przymusu bezpośredniego. Jak wspomniano wyżej, objawy choroby psychicznej mogą wywoływać u pacjentów zachowania o charakterze agresywnym lub autoagresywnym. Podjęcie działań przymusowych jest zarówno dla pacjenta, jak i dla personelu medycznego sytuacją o szczególnym charakterze. Lekarz lub pielęgniarka używający własnej siły muszą de facto zmusić pacjenta do podjęcia czynności, których on nie akceptuje. Brak reakcji ze strony pracowników ochrony zdrowia może z kolei skutkować wystąpieniem zagrożenia dla bezpieczeństwa pacjenta i/lub innych osób. Ustawa o ochronie zdrowia psychicznego w art. 18 wskazuje na procedurę, jaka musi zostać zastosowana w chwili pojawienia się konieczności użycia siły wobec osoby chorej bądź zaburzonej. W pierwszym rzędzie wymieniono tu następujące formy przymusu: unieruchomienia, izolację, przytrzymanie oraz przymusowe podanie leków. Bez względu na stan kliniczny, pacjent musi być powiadomiony o planowanym podjęciu wobec niego działań przymusowych. Czynności te mogą być podjęte tylko w ściśle określonych sytuacjach. Może je zlecić oraz musi osobiście nadzorować lekarz lub pielęgniarka, którzy zobligowani zostali do stałego monitorowania 
sytuacji oraz stanu pacjenta, którego przykładowo unieruchomiono za pomocą pasów (Kmieciak 2010, 272). Analizując szczególne sytuacje, jakie mogą pojawić się na terenie szpitala psychiatrycznego, warto również wspomnieć o tzw. przymusowej hospitalizacji psychiatrycznej. Jak wspomniano wyżej, standardem postępowania w zakresie przyjęcia do szpitala psychiatrycznego jest uzyskanie przez personel zgody pacjenta (lub jego opiekuna prawnego) na przyjęcie na dany oddział. W kontekście choroby psychicznej pojawić się może jednak sytuacja, w której wspomniana zgoda wyrażana jest w sposób wadliwy lub też pacjent nie ma możliwości wyrażenia zgody (znajduje się $\mathrm{w}$ stanie pobudzenia psychoruchowego, jest $\mathrm{w}$ silnym niepokoju, jest upośledzony intelektualnie, doświadcza halucynacji itd.). W podobnych sytuacjach personel niejednokrotnie zmuszony jest przyjąć pacjenta do szpitala pomimo sprzeciwu, jaki on wyraża. Omawiana w tym miejscu ustawa wprowadziła trzy tryby zalecanych postępowań:

a. tryb nagły: dotyczy sytuacji, gdy chory psychicznie pacjent stwarza zagrożenie dla własnego życia lub życia i zdrowia innych osób;

b. tryb obserwacyjny: dotyczy sytuacji, gdy co do danej osoby zachodzi podejrzenie, że może być chora psychicznie;

c. tryb wnioskowy: gdy konieczne jest podjęcie działań zmierzających do wsparcia medycznego osoby chorej psychicznie, nie potrafiącej zaspokoić swoich potrzeb życiowych (Ustawa, 1994).

W tym miejscu należy zaznaczyć, że każda decyzja lekarska o przymusowym przyjęciu pacjenta spotyka się z oceną ze strony sądu opiekuńczego. Ustawa przewiduje w tym miejscu rozwiązanie niespotykane w innych polskich aktach prawnych, polegające na tym, że sędzia udaje się do szpitala w celu wysłuchania pacjenta. Sąd zaś, po uprzednim zapoznaniu się z opinią biegłych, na odrębnym posiedzeniu podejmuje decyzję dotyczącą rzeczonej osoby (Duda 2006, 112-127).

Kończąc refleksje poświęcone szczególnej sytuacji, w jakiej znajduje się pacjent szpitala psychiatrycznego, warto zwrócić uwagę, iż w Polsce od 2005 r. funkcjonuje instytucja Rzecznika Praw Pacjenta Szpitala Psychiatrycznego. Utworzono ją i wprowadzono z inicjatywy psychiatrów, w wyniku nowelizacji Ustawy o ochronie zdrowia psychicznego. Celem działania takich urzędników jest przede wszystkim obiektywna analiza sytuacji, w jakiej znajduje się pacjent szpitala psychiatrycznego. Rzecznik zobowiązany jest do szczególnie skrupulatnej analizy położenia pacjentów, wobec których zastosowano przymus bezpośredni, położenia osób ubezwłasnowolnionych, a także osób przyjętych do szpitala bez ich zgody. Rzecznicy są w pełni niezależni od władz szpitala, na terenie którego pełnią swoją funkcję. Są pracownikami Biura Rzecznika Praw Pacjenta i posiadają m. in. prawo wstępu do miejsc, w których wykonywane są świadczenia zdrowotne, do swobodnego kontaktu z pacjentem, a także mają możliwość wnioskowania do władz szpitala (Kmieciak 2010, 216-217). 


\section{Refleksja podsumowująca}

Przedstawione wyżej analizy oraz refleksje historyczne skłaniają do próby udzielenia odpowiedzi na pytania postawione na wstępie.

Odnosząc się do pierwszego pytania (czy wyjątkowa sytuacja, w jakiej znajduje się pacjent chory psychicznie powoduje, iż nadal istnieje niebezpieczeństwo panowania/zapanowania personelu nad pacjentem?) zasadne jest zwrócić uwagę na to, że na przestrzeni dziejów szczególne położenie, w jakim znajdowali się pacjenci szpitala psychiatrycznego, czyniło z nich ofiary zachowań naruszających ich godność. Krępowanie pasami, izolowanie w piwnicach, przymusowa separacja, społeczne naznaczenie itd. to przykłady działań, jakie przez wieki podejmowano wobec chorych nie tylko w Europie. Choroba psychiczna stanowiła w przeszłości tajemnicę. Łączono jej pojawienie się ze zjawiskami natury duchowej. Z drugiej strony, już w czasach starożytnego Rzymu dostrzegano wyjątkowość sytuacji, w jakiej znajdowały się osoby psychicznie chore bądź zaburzone. Prawdą jest, iż dopuszczano krępowanie osób agresywnych, jednocześnie jednak wskazywano na konieczność zmniejszenia uciążliwości takiej sytuacji, uważając ją za rozwiązanie ostateczne. Śledząc losy pacjentów szpitali psychiatrycznych należy zdawać sobie sprawę z tego, że nadal istnieją obszary, w których personel może panować nad pacjentem. Nieodległe czasy ukazują rzeczywistość szpitala, w której pacjent był w pełni podległy woli personelu (Goffman 2011, 14-15). W tym miejscu warto wskazać, iż słowo „panowanie” ma dwa aspekty: negatywny i pozytywny. Jeden z nich unaocznia sytuację, w której lekarz/pielęgniarka, dostrzegając zły stan pacjenta, podejmuje wobec niego działania pozbawione wszelkiego szacunku wobec osoby chorej (Coelho 2009, 328-343). W tym miejscu najistotniejsza jest opinia personelu, który dążąc do udzielenia pomocy - polega na własnej, słusznej opinii. Powyższe działanie, określone w literaturze mianem hard paternalism, może jednak przybrać inną formę. Działanie przymusowe może być podyktowane przede wszystkim obiektywną oceną sytuacji, w której pacjent zagraża sobie lub innym. Czynności przymusowe wynikają zatem wprost $\mathrm{z}$ troski o dobro, bezpieczeństwo oraz zdrowie pacjenta, który nie potrafi $\mathrm{w}$ tym momencie ocenić sytuacji (Bujny 2007, 19-20). Tym samym, przymus bezpośredni w postaci np. unieruchomienia uzasadniony pragnieniem zabezpieczenia pacjenta przed "destruktywny(mi) objaw(ami) obłędu” (Belin 2001, 46). Działania siłowe podejmowane w medycynie wobec drugiego człowieka to sytuacja wyjątkowa i wymagająca przestrzegania szczegółowych zasad i procedur. Istnienie takich zasad i procedur podyktowane jest przede wszystkim troską o godność osoby chorej. Stan psychozy, autyzmu, otępienia, głębokiej depresji, demencji lub manii może powodować znaczne ograniczenie zdolności postrzegania rzeczywistości u pacjenta. W tym miejscu pojawić się może pytanie: czy w podobnych stanach klinicznych konieczne jest uprzedzenie pacjenta o zamiarze zastosowania wobec nich przymusu bezpośredniego? Można przecież uznać, że np. ograniczone zdolności intelektualne utrudniają wybranym grupom chorych zrozumienie 
kierowanego do nich komunikatu. Warto jednak zaznaczyć, że przekazanie wspomnianej informacji wynika wprost z zasady poszanowania godności drugiego człowieka. Podobne postępowanie znajduje uzasadnienie $\mathrm{w}$ treści preambuły do ustawy o o.z.p., zgodnie z którą „zdrowie psychiczne jest fundamentalnym dobrem osobistym człowieka, a ochrona praw osób $\mathrm{z}$ zaburzeniami psychicznymi należy do obowiązków państwa..." (Ustawa, 1994).

Choroba psychiczna nadal stanowi tajemnicę, która $\mathrm{z}$ jednej strony fascynuje, a z drugiej - wzbudza lęk (Świtaj 2005, 139-140). Nie znamy i nie potrafimy w pełni wyjaśnić przyczyn pojawiania się zaburzeń psychotycznych. Nie znamy czynników biologicznych, które bezpośrednio wpływać mogą na wystąpienie np. omamów wzrokowych lub urojeń. Wiedza o wspomnianych typach schorzeń czerpana jest często z obserwacji zachowania osób hospitalizowanych. Inna, nie mniej ważna wiedza jest bardziej dostępna: dotyczy ona praw pacjenta szpitala psychiatrycznego, odnoszących się do jego wyjątkowej sytuacji, w której wsparcie terapeutyczne musi niejednokrotnie obejmować ochronę pacjenta przed zagrożeniem, jakie stanowi on dla samego siebie $^{3}$.

\section{Literatura}

Bielicka, J. 2010. „Refleksje wykładowcy”. W Białek, I. et al. (red.), Moja wędrówka. Refleksje studentów i wykładowców UJ o chorobie psychicznej i studiowaniu. Kraków: Biuro ds. Osób Niepełnosprawnych Uniwersytetu Jagiellońskiego.

Bilikiewicz, A. 2006. „Zarys psychiatrii oraz jej miejsce w kulturze i wśród innych dyscyplin nauki”. W Blikiewicz, A. (red.), Psychiatria podręcznik dla studentów medycyny. Warszawa: Wyd. Lekarskie PZWL.

Balter, M. 2001. Dziecko niczyje. Warszawa: Wydawnictwo BIS.

Belin, S. 2001. Schizofrenia. Jak pobudzić rozwój osobowości pacjenta. Tłum. J. Kubitsky. Gdańsk: GWP.

Boratyńska, M. \& Konieczniak, P. 2003. Prawa pacjenta. Bydgoszcz: Wydawnictwo Difin.

Bujny, J. 2007. Prawa pacjenta - między autonomiq a paternalizmem. Warszawa: Wydawnictwo C. H. Beck.

Coelho, P. 2009. „Odpoczywając w więzieniu.” W Grace, P. et al., Wolność istota bycia człowiekiem. Warszawa: Wyd. G + J.

Cohen, J. \& Levi, S. 1998. Chory psychicznie nadużywajacy substancji psychoaktywnych. Czyj pacjent? Tłum. Ł. Święcicki. Warszawa: PARPA.

Duda, J. 2006. Komentarz do ustawy o ochronie zdrowia psychicznego. Warszawa: Lexis Nexis.

${ }^{3} \mathrm{~W}$ prezentowanej pracy autor wykorzystał wyniki analiz przeprowadzonych $\mathrm{w}$ ramach przygotowywania własnej pracy doktorskiej. 
Grochowski, L. 1990. „Początki nauczania dzieci upośledzonych i zorganizowanej opieki nad moralnie zaniedbanymi". W Mauersberg, S. (red.), Dzieje szkolnictwa i pedagogiki specjalnej. Warszawa: PWN.

Goffman, E. 2011. Instytucje totalne. O pacjentach szpitali psychiatrycznych $i$ mieszkańcach innych instytucji totalnych. Gdańsk: Gdańskie Wydawnictwo Psychologiczne.

Gut, A. 2010. Eutanazja - ukryte ludobójstwo pacjentów szpitali psychiatrycznych w Kraju Warty i na Pomorzu w latach 1939-1945. Warszawa: $\quad$ http://www.ipn.gov.pl/portal/pl/2/730/Eutanazja. Dostęp z dn. 4.07.2012.

_8211_ukryte_ludobojstwo_pacjentow_szpitali_psychiatrycznych_w_Kr aju_Wa.html.

Katolo, A. 2012. Eutanazja i eugenika - doświadczenia hitlerowskie. Gliwice: Instytut Globalizacji.

Kępiński, A. 1970. „Prognoza psychiatryczna”. Znak 190: 241.

-_-. 2001. Rytm Życia. Kraków: Wydawnictwo Literackie.

- - . 2010. „Rzecznik praw pacjenta szpitala psychiatrycznego jako strażnik ładu społecznego". W Moczuk, E. \& Sagan, B., III Forum Socjologów Prawa. Rzeszów: WPiA.

- - - 2011. „Prawa pacjenta szpitala psychiatrycznego - historia i współczesność”. W Maciaszek, J. \& Bucoń, P. (red.), Ochrona zdrowia psychicznego - wybrane zagadnienia społeczno prawne. Janów Lubelski: Wydawnictwo Katolickiego Uniwersytetu Lubelskiego.

- - - 2010. „Poszanowanie praw małoletniego pacjenta w szpitalu psychiatrycznym a doświadczenie choroby psychicznej". W PłonkaSyroka, B. \& Skrzypek, M. (red.), Doświadczanie choroby $w$ perspektywie nauk humanistycznych, społecznych i medycznych. Wrocław: Akademia Medyczna im. Piastów Śląskich.

Kurowski, K. 2010. „Ewolucja regulacji prawnych Organizacji Narodów Zjednoczonych w zakresie problematyki praw osób niepełnosprawnych". W Podgórska-Jahnik, D. (red.), Problemy rzecznictwa i reprezentacji osób niepełnosprawnych. Łódź: Wyższa Szkoła Pedagogiczna.

Michalik, G. 2008. „Historia psychiatrii. Od prehistorii do końca starożytności w kontekście kulturowym, społecznym i historycznym". W PłonkaSyroka, B. (red.), Antropologia medycyny i farmacji $w$ kontekście kulturowym, społecznym i historycznym. Wrocław: Akademia Medyczna im. Piastów Śląskich.

Mik, C. 1998. Wprowadzenie do prawa międzynarodowego praw człowieka. Warszawa: Helsińska Fundacja Praw Człowieka.

Magowska, A. 2008. „Polsko - niemieckie interakcje w zakresie psychiatrii w latach 1906-1939". W Sachs, M., Płonka-Syroka, B., \& Dross, F. (red.), Współpraca na polu medycyny między Niemcami i Polakami. Wrocław: Akademia Medyczna im. Piastów Śląskich.

Półtawska, W. 2001. Stare rachunki. Częstochowa: Edycja św. Pawła. 
Pużyński, S. 1995. „Problemy etyczne i prawne stosowania leków psychotropowych $\mathrm{w}$ świetle postanowień międzynarodowych". W Siwiak-Kobayashi, M. \& Leder, S. (red.), Psychiatria i etyka. Kraków: Biblioteka Psychiatrii Polskiej.

Ryn, Z. 2015. Eugeniusz Brzezicki - psychiatra (1890-1974). Kraków: Medycyna Praktyczna - Psychiatria.

Świtaj, P. 2005. „Piętno choroby psychicznej”. Postępy Psychiatrii i Neurologii 14.

Totsuika, E. 1990. "The History of Japanese Psychiatry and the Rights of Mental Patients." Psychiatrie Bulletin 14.

Veggebrerg, S. K. 1998. Leczenie umysłu. Warszawa: Prószyński i S-ka. 


\title{
Błażej Kmieciak (Łódź)
}

\author{
Choroba psychiczna - cierpienie, które zmieniło prawo \\ (Mental Disease - Suffering That Was Able to Change Law)
}

\begin{abstract}
Throughout history, patients of psychiatric institutions were often treated improperly. These individuals were isolated, humiliated and excluded. On the other hand treatment frequently contravenes the subjective/agentrelative positions and rights of people with mental disorders in implementing so-called positive changes. The perception of improper handling of cited group of patients sometimes constituted the beginning stage of the activities, aimed at taking responsible care of people with schizophrenia or depression. That concern also has a unique character, involving the necessity to continue to take coercive action against the patient. The paper is intended to depict the past and current situation of psychiatric institution patients. It will also present the fundamental principles that currently exist for the protection of the rights of people treated in these hospitals.
\end{abstract}

Keywords: Psychiatric institution patient, rights of mental patient, violence, ombudsman, The Second World War

Doi: $10.14746 /$ eip.2014.2.9 